DOI: https://doi.org/10.31933/dijemss.v2i5

Received: $16^{\text {th }}$ June 2021, Revised: $25^{\text {th }}$ July 2021, Publish: $31^{\text {th }}$ July 2021

\begin{tabular}{|c|c|c|}
\hline PINASTIS & $\begin{array}{l}\text { DIJEMSS } \\
\text { DINASTI INTERNATIONAL JOURNAL } \\
\text { OF EDUCATION MANAGEMENT AND } \\
\text { SOCIAL SCIENCE }\end{array}$ & $\begin{array}{r}\text { https://dinastipub.org/DIJEMSS } \\
\text { editor@dinastipub.org } \\
08117401455\end{array}$ \\
\hline
\end{tabular}

\title{
THE EFFECT OF SCHOOL WELL-BEING ON GRIT WITH THE GROWTH MINDSET AS MEDIATOR
}

\author{
Ida Saidah', Asmadi Alsa ${ }^{2}$, Anizar Rahayu ${ }^{3}$ \\ 1)Persada Indonesia University YAI Jakarta, Indonesia, iedasaidah@yahoo.com \\ 2)Persada Indonesia University YAI Jakarta, Indonesia, asmalsa@ugm.ac.id \\ ${ }^{3)}$ Persada Indonesia University YAI Jakarta, Indonesia, anizar.rahayu@gmail.com
}

Coresponding Author: Ida Saidah ${ }^{1}$

\begin{abstract}
The character of grit is to emphasize the importance of desire, interest so that students can achieve the desired achievements when students have resilience and persistence. There are still many schools that have learning targets that emphasize the value of achievement rather than character building. As the result, it can be found the phenomenon of students who are not enthusiastic to maintain interest, do not have the resilience to overcome obstacles and challenges, and have a need for achievement with an unyielding mentality. The purpose of this study is to examine the theoretical model of the effect of school well-being on grit with a growth mindset as a mediator. Three hundred and thirteen school-age students were surveyed. The research instrument used in this study is a questionnaire based on a Likert scale model and being tested through several stages to obtain valid and reliable instrument. The finding suggests that theoretical model fits with the empirical data. However, contrary to expectations, results from SEM analyses indicates that growth mindset has no positive and significant effect in mediating influence of school well-being on grit of students from 10 Integrated Islamic Elementary Schools in four sub-districts of Bekasi Regency. Rather, results show two direct effects; that growth mindset and grit go hand in hand and that school wellbeing supportd growth mindset. Gender differences are observed in growth mindset and school well-being. Theoretical and practical implications for parents and teachers are also discussed.
\end{abstract}

Keywords: Grit, Growth Mindset, School Well-Being

\section{INTRODUCTION}

Grit is great passion, spirit and enthusiasm with perseverance, resilience, consistency to achieve long-term goals, goals that are not easy but very meaningful and worth fighting for (Duckworth,2007). Based on the researcher's personal experience, the researcher found that there is no strong grit character in private 
elementary schools' students in North Cikarang, East Cikarang, Central Cikarang and South Cikarang area, Kabupaten Bekasi, compared to students in Malaysia. For example, when Integrated Islamic Elementary School Plus Cordova students participated in the Quest Student program in Malaysia, it is seen that Malaysian children have high enthusiasm to stay in school from 07.00 to 16.00 Malaysian time, while Indonesian children who participated in the same class at the school, at 14.00, already complain about fatigue and loss of focus. When they were conducting a discussion, Malaysian children were able to hold out and defend their opinions for 2 hours, while Indonesian children were not able to stay focused for a long time. Considering that in the future the competition between the nations' future generation is getting tougher, it is important to cultivate the spirit of maintaining effort and interest, strong motivation, resilience in trying to overcome obstacles and challenges, persistence, the need for achievement with an unyielding mental through grit as early as possible.

Duckworth (2011) states that the best way to build grit is by developing the growth mindset. Dweck (2006) from Stanford University stated that the growth mindset is the belief that the ability to learn can change with effort. Dweck $(1999,2007,2010)$ and Duckworth (2007) in Hochanadel and Finamore (2015) state that a growth mindset is a good idea to build grit. This means that individuals with a growth mindset think that the effort and process of achieving something are more important than the results themselves. Their focus is on the learning process, not the outcome. As revealed by Wellington Learning and Research Center and Harvard Graduate School of Education (2014) that the school environment in educational process influences and supports the growth mindset. This research shows that teaching students with brain capacity to adapt based on experience is an effective way to cultivate growth mindset (Dweck, 2006). Educators who are part of the school well-being dimension can influence students' growth mindset.

Creatively arranged learning programs will become the trigger for the emergence of students' growth mindset. Educators provide a sense of comfort for students to take part in learning, foster openness and opportunities for students to continue to grow according to the capacity of each student. A school environment that is always kept together for cleanliness and tidiness will make students feel comfortable being in school to carry out learning activities. Therefore, this study will examine the role of the growth mindset in mediating the influence of school well-being on grit in students at several Integrated Islamic Elementary Schools in Bekasi.

\section{LITERATURE REVIEW \\ Grit}

Often professors, teachers and educators say that IQ (Intelligences Quotient) is not the only difference between the best and the worst students. An American psychologist Angela Lee Duckworth (2007) found that one characteristic that emerged as a significant predictor of a person's success was not talent or skill or good looks, or physical health or IQ but grit. Grit is a very high passion, enthusiasm and enthusiasm with very high perseverance, resilience, consistency to achieve long-term goals, goals that are not easy but very meaningful and worth fighting for (Duckworth, 2007). Grit is character. One way to think about grit is to understand how it relates to aspects of character. Duckworth (2016) found three clusters in assessing grit 
as a character, first: interpersonal strength/moral character including: generosity, gratitude, empathy, self- control. The second cluster is intrapersonal strength/will power, which is how it relates to the ability to resist temptation within oneself, goals, conflicting impulses, selfcontrol, delaying gratification, optimism, always thinking about what to do to make the future better. While the third cluster is intellectual power; the power to grow a healthy mind, curiosity, creativity, open mind, fair thinking towards different opinions. Duckworth (2016) says that grit is an aspect of character that can be taught and formed through motivation and action. Motivation that leads to goals, values, beliefs and self-identity. The character in children can be changed by focusing on what they consider to be values, what they think is important, what they believe to be possibilities in life, what they believe to be true and most importantly what their identity is as a human, and how they think about themselves. While action arises from learning about abilities and strategies. Grit was measured using the Grit Scale tool made by Duckworth (2007) which contains 12 items. This scale measures; attention to not being easily distracted, setting goals, maintaining interest, trying hard in challenges, being able to get work done, persistent in trying.

\section{Growth Mindset}

Dweck (2006) states that mindset is is a simple belief that has the power to change a person's psychology (thoughts, awareness, feelings, attitudes) and ultimately can change a person's life. Dweck (2006) in his book 'Mindset: The New Psychology of Success', suggests two types of mindset: 1). Fixed Mindset is the belief that one's nature is fixed, the belief that one's qualities are fixed. Fixed mindset is the belief in seeing situations as fixed, rigid and unchanging. Students with a fixed mindset believe that intelligence is more dependent on innate ability than effort, view failure as evidence of a lack of self-immutable abilities, as a result they are easy to give up from tasks when facing or making mistakes or difficulties (Dewck, 2006; Robin \& Pals , 2002). 2). The growth mindset is the belief that a person's basic qualities can basically be cultivated with a certain amount of effort. A person with a growth mindset believes that intelligence can be developed, that the brain is like a muscle that can be trained. This passion leads to a desire to improve. Wellington Learning and Research Center and Harvard Graduate School of Education (2014), citing Dweck (2006) that students with a growth mindset (incremental theorist) try to understand that intelligence and academic skills can change, success largely depends on the amount of effort put in, not only depend on the original talent. Students with a growth mindset see failure as a potential opportunity for instructive feedback and are thus more likely to learn from their mistakes.

Measurement of growth mindset using Theory of Intelligence Scale (TIS) developed by Dweck and Levy (in Hong, Chiu, Dweck, Lin \& Wan, 1999) which has been modified to believe that intelligence, talent and traits are not a function of heredity; likes to accept challenges and take them seriously; looking forward from failure to self-improvement; have a positive view that effort and hard work contribute to success; learn from criticism and input as feedback on success; and looking forward from failure to self- improvement. 


\section{School Well-Being}

School is an arena for groups, individuals to interact with each other. Groups, individuals are a means of learning about social roles and norm boundaries (Holander in Bachrie, 2009). According to the National Education System Law No. 20 of 2003, learning is a process of interaction between students and educators and learning resources in a learning environment. Therefore, the role of the learning environment is very large in the educational process. The learning environment is expected to prosper students, so that in following the learning process students can develop optimally and get the best results. The learning process in schools involves the participation of teachers as educators, other students and all existing elements so that the learning process runs well. So, between students, teachers and schools must be able to synergize with each other because learning is not limited to the process of transferring knowledge, but also learning to develop students' potential optimally, build character and life values, as well as positive emotions that will shape students' personalities.

Well being refers to the condition of an individual or group of individuals in a distinctive domain, such as physical, social, economic, psychological, and spiritual. High wellbeing is related to individual positive experiences. Meanwhile, low well-being is related to negative experiences or events in individuals (Shaari, Amar, Harun, \& Zainol, 2017). The concept of well being was brought into the public and educational domains by positive psychologists (Seligman, 2011). The school environment is referred to as the main setting that has a crucial role in realizing the well-being of students. Through a positive school climate and close relationships as well as a sense of belonging to the school it is associated with a sense of well-being, resilience, and academic and social adjustment in students (Evans, Martin, \& Ivcevic, 2018). Students who have well-being will feel healthy, comfortable, happy, valuable, and prosperous so that they will tend to have a positive assessment of school, prefer school, can learn effectively, and make a positive contribution to school (Papalia, Olds, \& Feldman, 2009; Konu \& Rimpelä, 2002). In some literature, well-being in schools is known as school well-being (Wahidah and Royanto, 2019).

School well-being was developed based on the theory of well-being by Allardt. Alldart (in Konu and Rimpela 2002) defines school well-being as a condition that allows a person to fulfill his basic needs. These needs are divided into 3 categories, namely Having, Loving and Being. This concept was developed by Konu and Rimpela (2002) and adds one more category, namely health status. So that in the concept of school well-being there are four aspects, namely having, loving, being and health. The four aspects of school well-being are comprehensive enough to describe students' well-being while at school.

\section{Hypotheses and Contribution to Existing Knowledge}

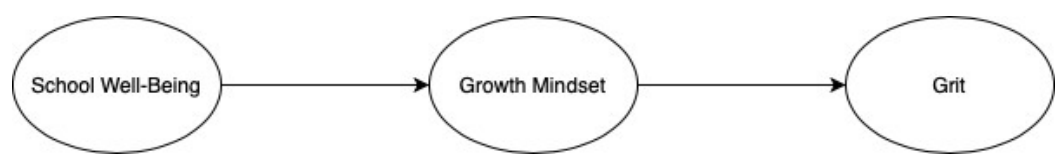

Figure.1 
The following are the research hypotheses that will be tested in this study:

1. Theoretical model on the influence of School Well-Being on Grit mediated by Growth Mindset fits with the empirical data

2. Growth Mindset has a positive and significant effect on the Grit of students from 10 Integrated Islamic Elementary Schools in four sub-districts of Bekasi Regency which are the objects of research

3. School Well-Being has a positive and significant effect on the Growth Mindset of students from 10 Integrated Islamic Elementary Schools in four sub-districts of Bekasi Regency which are the objects of research

4. School Well-Being has a positive and significant effect on Grit mediated by the Growth Mindset of students from 10 Integrated Islamic Elementary Schools in four sub-districts of Bekasi Regency which are the object of research

School well-being and growth mindset have not become the focus of attention from parents and educators, so research on grit and the factors that influence it especially on elementary school students is important to do. Currently there are not many studies on grit and the factors that influence it, so it is still difficult to find national and international journals that can explain grit. This is because the theoretical concept of grit has just been introduced in the world of psychology, so there are not many theories and research focused on grit and growth mindset, especially for children in the age range of 6-12 years. Most of the research on growth mindset and grit was conducted on college students. In Indonesia, especially in its elementary schools, research on grit and its influencing factors has not been widely found so that researcher hopes that this research will have novelty value.

\section{RESEARCH METHOD}

\section{Participants and Procedures}

Participants in this research comprised a total of 313 students from 10 Integrated Islamic Elementary Schools (SDIT) in 4 sub-districts of Bekasi regency. The sample was consisted of 120 boys (38\%) and 193 girls (62\%). The majority of respondents's age were 10 years old. Data collection was carried out for 14 days in February 2020. Students filled out the questionnaire during class time and were assisted by three research assistants. Samples were taken proportionally using stratified random sampling method.

\section{Measures}

The research instrument is in the form of a questionnaire. The questionnaire model was arranged based on a Likert scale ranging from 1 to 5 (very inappropriate, inappropriate, less appropriate, appropriate and very appropriate). The grit variable is measured using the measuring instrument made by Duckworth (2007) which contains 12 items that have been translated into Indonesian and adapted by the researcher. The growth mindset scale consists of 14 items and is measured using the Theory of Intelligence Scale (TIS) developed by Dweck and Levy (in Hong, Chiu, Dweck, Lin \& Wan, 1999) which has been modified by the researcher. The school well-being variable is measured based on the measuring instrument developed by Konu and Rimpela (2002) and comprises 30 items. 


\section{The Results of Instrument Trial Content Validity}

Testing the validity of the content is done by asking for an assessment of seven experts who have an understanding of the variables to be measured and have an understanding of the rules of writing Indonesian. The results of the expert's assessment were then calculated using the Aiken's V (1985) formula. By using the Aiken's V (1985) formula, an item is declared content valid if it has a $\mathrm{V}$ value of 0.75 and above. The results of the validity test of the grit variable content show that of the 12 items on the grit measuring instrument there are 8 items that are valid because they have a value of $\mathrm{V} 0.75$. Because the grit variable is an endogenous variable, it is necessary that two indicators are represented by many items so that the 4 unvalid items are justified and becomes an acceptable and valid item. Then the grit variable content remains 12 items. For other variables, there are 9 of 14 items and 26 of 30 items that are valid for growth mindset and scholl well-being, respectively.

\section{Item Difference Test}

To determine the value of the differentiating power of the items in this study, the researcher conducted an internal consistency correlation test, namely the item correlation model with the total score. According to Freidengergh (1995) items have good distinguishing power if the correlation coefficient value is 0.3 . If the value of 0.30 is not met, the correlation value can be lowered to 0.25 . the result for grit variable comes with 5 of 12 items that have good distinguishing power. Next, the researcher took 2 other items that had the highest correlation values because not all indicators are represented by items so that the total is 7 items. The same case also happens with growth mindset and school well-being variable where 2 items that are not qualified but have the highest correlation value are taken back so that 7 out of 9 and 16 of 26 are used in this research respectively

\section{Test Item Validity with Confirmatory Factor Analysis (CFA)}

Confirmatory Factor Analysis (CFA) technique is a form of factor analysis by confirming several empirical constructs that are assumed to be factors of latent constructs (Widhiarso, 2011). This CFA analysis is carried out to test whether the items on a scale are proven to be a unit of measurement that measures the same construct. An item in a factor must be statistically significant with a standard loading above 0.5 , although ideally it is 0.7 (Hair, et al., 2010). CFA can also be used to identify latent factors that can explain the variation and covariance of the indicators that compose it (Brown, 2006). The process of analyzing the results of the validity test uses Confirmatory Factor Analysis (CFA) with the help of Amos version 24.0. CFA analysis in this study uses two approaches, namely 1st order and 2nd order. The 1st order approach is used for unidimensional research variables, while the 2nd order approach is for multidimensional research variables. Widhiarso (2011) stated that the two-level factor analysis model is one of the measurement models in SEM (Structural Equation Model). The result shows that all indicators of each variable have been represented. There are 19 total items represented, namely, 4 items from grit variable, 3 items from growth mindset variable, and 4 items from school well-being variable. 


\section{Statistical Analysis}

The data analysis method in this study is descriptive analysis and structural model analysis. Descriptive analysis is used to get an overview of the research data using the SPSS 23 program for windows while data analysis is processed with Amos version 24.0 program. Data analysis consist of two stages: 1). Testing the suitability of the measurement model with the data in the field 2). Testing the structural relationship hypothesis in the theoretical model whether it fits with empirical data.

\section{RESULTS AND DISCUSSION \\ Descriptive Analysis}

The distribution of questionnaires with five measuring instruments were conducted to the 313 respondents.

Based on the results of the study, researcher obtained the following data:

a. Respondents in the high grit category were 59 people $(18.85 \%), 203$ respondents in the medium grit category $(64.86 \%)$, and respondents with low grit category as many as 51 people $(16.29 \%)$.

b. Based on the results of the Chi Square test, it is known that all $p$ values are $>0.05$. This means that the level of grit in the respondents is not influenced by differences in gender, age differences, differences in grade levels and differences in school origin

c. There were 39 respondents in the high growth mindset category (12\%), 237 respondents in the medium growth mindset category (76\%), and 37 respondents in the low growth mindset category (12\%).

d. Based on the results of the Chi Square test, it is known that the respondents' level of growth mindset is influenced by gender differences. The results of the factor loading calculation conclude that the male gender has an effect on the level of growth mindset, while the female gender has no effect on the level of growth mindset. The results of the Chi Square test also show that the respondents' level of growth mindset is not influenced by differences in age, differences in grade levels and differences in school origin.

e. Respondents with high school well-being were 44 people (14.06\%), respondents with moderate school well-being were 215 (68.69\%), and respondents with low school wellbeing were 54 people (17.25\%).

f. Based on the results of the Chi Square test, it is known that the respondents' level of growth mindset is influenced by gender differences. The result of factor loading calculation concludes that male and female sexes are equally influential on the level of school well-being. The results of the Chi Square test also show that the respondents' level of school well-being is not influenced by differences in age, differences in grade levels and differences in school origin.

\section{Structural Equation Model Analysis}

Data analysis is explained by using SEM, namely the measurement model and structural model. The first stage is the assumption test which consists of normality, linearity and heterodasticity tests. Ferdinand (2000) said that there are four main assumptions of SEM, namely 1). data follows a normal distribution, 2). all relationships between variables are linear, 
3). there is no perfect multicollinearity between exogenous variables, and 4). there are no data outliers that have extreme values compared to other variables the other values. According to Hair et al (2014) the most basic of the four assumptions is normality.

\section{Assumption Test: Normality Test, Linearity Test and Heterodascity Test}

To find out whether the requirements for the analysis are met, the assumption test of the research data consisting of the normality test, linearity test and heterodasticity test must be carried out first. Based on the results of the data normality test using the Kolmogorov Smirnov test, it is known that the significance value of all variables in this study is $>0.05$, it can be concluded that all variables in this study are normally distributed. Therefore, it can be continued to the next test, namely linearity test.

The linearity test was conducted to determine whether two variables had a significant linear relationship or not. The linearity test on SPSS usually uses a test for linearity with a significance level of 0.05 . Based on the results of the linearity test, it is known that all independent variables have a significance value $>0.05$. It can be concluded that all independent variables in this study have a linear effect on the dependent variable. Therefore, it can be continued in the next test, namely the heterodasticity test.

Heterodasticity test is a type of classical test that serves to determine whether all independent variables have the same variance or not. In the process of parametric testing requires that the data on the independent variables must have the same variance. To carry out the heterodasticity test in this study, the Glejser test was carried out. It is known from the result that all independent variables have a significance value $>0.05$. Therefore, it can be concluded that there is no heterodasticity in all independent variables. This means that all independent variables have the same variance.

\section{Structural Model Testing}

On this testing the researcher using t-Value with a significance level of 0.05 . The test results of the entire hypothesis proposed in this study are as follows:

1) Minor hypothesis 1: Growth mindset has a positive and significant effect on grit in students from 10 schools in four sub-districts of Bekasi Regency which are the objects of this research.

Conclusion: Because the $\mathrm{t}-$ Value or $\mathrm{CR}>$ is $2.170 \geq 1.967$ or the $\mathrm{P}$ value is $0.030 \leq$ 0.05 , the hypothesis is accepted, meaning that growth mindset has a positive and significant effect on grit in students from 10 schools in four sub-districts of Bekasi Regency which are the object of this research.

2) Minor hypothesis 2: School well-being has a positive and significant effect on the growth mindset of students from 10 schools in four sub-districts of Bekasi Regency which are the objects of this research. Conclusion: Because the t-Value or CR>3.680 $\geq 1.967$ or the $\mathrm{P}$ value has a $* * * *$ sign, the hypothesis is accepted, meaning that school well-being has a positive and significant effect on the growth mindset of students from 10 in four sub-districts of Bekasi Regency which are the objects of this research. Furthermore, to determine the indirect effect of each exogenous variable on the 
endogenous variable through the mediator variable, the researchers conducted the Sobel test.

3) Minor hypothesis 3: School well-being has a positive and significant effect on grit mediated by growth mindset on students from 10 schools in four sub-districts of Bekasi Regency which are the objects of research.

Conclusion: Because the loading factor value is 0.153 and tcount value: $1.463<\mathrm{t}$ table: 1.65 , with $\mathrm{P}$

value: $0.144>$ : 0.05 , it means the growth mindset is not significant in acting as the mediator on the effect of school well-being on grit.

Based on the standardized total effect output value, the total effect of school wellbeing and growth mindset variables on grit is known to be 0.153 . So, it can be concluded that the total effect of school well- being and growth mindset on grit is $15.3 \%$.

\section{DISCUSSION}

Empirical issue in this study is grit and growth mindset is a theoretical concept that has not been known for so long in the world of Psychology, particularly education, so theory and research focuses on the grit and the growth mindset, especially in the age range of 6-12 years, is still limited. The age range of 6-12 is the age where mental development takes place very quickly. A good environment will take advantage of this momentum to form strong mental values and positive character at least since the child attends elementary school (Siswina, 2016). Therefore, this research can have novelty value in testing the theoretical grit and growth mindset at an early age.

Based on the results of the Chi Square test, it is known that the level of grit is not influenced by differences in gender, age, class rank, and school origin because being gritty is a personality that stands on its own abilities and comes from internal motivation (Duckworth, 2007). This is in line with the results of interviews that researchers conducted with several teachers from each school which stated that students' persistence and persistence were not relied on class and age but individual maturity. It is also known that the level of growth mindset and school well-being is not influenced by age, class rank, and school origin but by gender differences. The result of factor loading analysis for boys is higher than for girls. This means that male respondents have a higher growth mindset and school well-being than female respondents. This result can be understood when looking at the psychological differences between women and men, it shows that men prioritize logic in their thinking, while most women generally prioritize feelings.

In this study, based on the test results of the table fit index, it shows that the theoretical model on the influence of School Well-Being on Grit which mediated by Growth mindset fits with the empirical data. According to Joreskog and Sorborm (1989) what is meant by fit is the suitability between the sample covariance matrix and the estimation of resulted population covariance matrix. In general, it can be explained that the diversity in the sample is portraying the diversity in the population. Thus, the theoretical model that the researcher offer can be used 
as an analytical model in analyzing the grit of students from participated schools and can be duplicated to different characteristics of respondets (e.g., high school student, college students)

However, the result of sobel test shows that growth mindset has no significance effect on mediating the school well-being to grit. Researcher considers that some limitations may affect the result. First, the respondents are too young. They are still in elementary school age grade 4,5 and 6 . In the age range of 8-12 years, the cognitive ability related to thinking skills such as the ability to remember, reason with ideas, imagination, and creativity has not developed optimally and still have limitations (Bjuri, 2018) so that they were not optimal in providing answers to the questionnaire. Students were also in a hurry when completing the questionnaire. They did not want to think too long, did not focus on doing it, and were easily influenced by their friends. Second, the length of research time given from each school is not equal; some gave half an hour, some gave one hour. Filling out the questionnaire within a limited time can give results that are not optimal.

\section{Theoretical Implications}

This research aims to explore the role of the growth mindset as a mediator or intervention in the formation of children's character. Character education itself is very important because character has a higher position than intelligence (R.W Emerson in Lickona, 2015). There is no success without character. Character is able to make people survive through adversity and in the character of citizens lies the welfare of the nation (Lickona, 2015). However, the results of previous studies are known to focus more on the role of growth mindset and grit as a mediator or intervention on an achievement or academic score achievement rather than character building itself. In addition, it may also be possible to underline studies that criticize the growth mindset, such as the research which states that growth mindset interventions to increase students' intelligence and therefore increase their grades do not work in many situations (Sisk et al., 2018). The other research also states that to help students become more grittier, a growth mindset intervention may not be the right choice. Instead, education policy makers and practitioners may consider focusing on goal commitment. Helping students to set and develop their long-term goals by providing a supportive environment to achieve those goals may increase their grit level (Tang et al., 2019).

Given that no previous research has been found that can be used as a reference or comparison for the results of this study, plus references related to criticism of the growth mindset, this should trigger further research to evaluate the role of the growth mindset especially with regard to character building. Future researchers are expected to pay attention to other variables that can build and shape the gritty of elementary school-age children. Given that grit is a character, it requires a long process and time for children to acquire. The process of shaping good character can start to be familiarized at the elementary school age.

\section{Practical Implications}

Based on the findings in this study, the researcher provides practical suggestion for schools participated in this research to use the results of this research by socializing it through providing the materials and programs about school well-being, growth mindset and grit to teachers, parents and students so that each party can have the same understanding and 
be able to carry out what their task is according to their role. Because educating children is the responsibility of parents who are in synergy with the school and its environment. Schools also can provide materials, programs and improve facilities and infrastructure that support the creation of school well-being. Psychologically, fun learning with interactions between educators and students will bring the teaching and learning situation to be comfortable and harmonious, so that it can foster students' learning enthusiasm and motivate them to be actively involved in every teaching and learning process. School facilities and infrastructure need to be repaired and maintained properly. The school curriculum with its local content needs to be evaluated, improved and its implementation need to be well controlled. The upgrading of teachers' competencies and skills need to be carried out on an ongoing basis. Everything needs to be done so that students feel comfortable and happy in carrying out their learning activities, and it can facilitate students to shape many characters within themselves.

\section{CONCLUSION}

This study examines the effect of school well-being on grit with the growth mindset as mediator. Our findings suggests that the theoretical model fits with the empirical data. However, the sobel test shows that growth mindset does not mediate the relation between school well-being and grit. This result may be influenced by the age of respondents that are too young which are not facilitated with more proper data collection method. As we more focus on character building on children which is represented by grit rather than academic achievement, our theoretical implications suggest for further research to evaluate the role of the growth mindset in building character or grit considering a number of criticisms adressed to growth mindset. Future researchers are expected to explore other variables that can build and shape the gritty of elementary school-age children where mental development takes place very quickly at that age.

\section{REFERENCE}

Ahmad, J.N. (2010). The use of School Well-Being in International Standard High Schools (SMA) as a

Barometer of School Evaluation. Journal of the University of Indonesia.

Akbağ, M., \& mmet, D. (2017). Predictive Role of Grit and Basic Psychological Needs Satisfaction on

Subjective Well-Being for Young Adults. Journal of Education and Practice, 9.

Arif, I. S. (2016). Positive Psychology: A Scientific Approach To Happiness. Jakarta: Gramedia Pustaka

Utama.

Arslan, S. (2014). The Relationship between Achievement Goal Orientations and Grit. Eğitim ve Bilim.

Arya, B., \& Lal, D. S. (2018). Grit and Sense of Coherence as Predictors of Well-Being. Indian Journal of

Positive Psychology, 9(01).

Azwar, S. (2015). Reliability and Validity. Yogyakarta: Student Library.

Bask, M. \& Salmela-Aro, K. (2012). Burned out to Drop Out: Exploring the Relationship between School Burnout and 142 I Jurnal Psychology Talenta Vol. 4 No. 2 The Role 
of Persistence in the Growth Mindset Relationship of School Dropouts. Eur J Psychol Education 2013: 28:511-528.

Bujuri, D. A. (2018). Analysis of Primary Childhood Cognitive Development and Its Implications in

Teaching and Learning Activities. Journal of Educational Sciences, 9(1), 37-50.

Chan, D.W. (2012). Life Satisfaction, Happiness, and the Growth Mindset of Healthy and Unhealthy

Perfectionists Among Hong Kong Chinese Gifted Students. Roeper Review, 34(4), 224-233.

Chrisantiana, T. G., \& Sembiring, T. (2017). The Effect of Growth and Fixed Mindset on Grit in Students of the Psychology Faculty, University of " $X$ " Bandung. Humanitas (Journal of Psychology), 1(2),133.

Dabbar, S. (2014, July 7). Grit: Redefining a Quotient for College Admissions. Retrieved from Admission

Smarts: http://www.admissionsmarts.com.

Dachlan, U. (2014). Complete Guide to Basic Structural Equation Modeling. Semarang: The Lantern of Science.

Desmita. (2015). Developmental Psychology. Bandung: PT Pemuda Rosdakarya.

Duckworth, A. (2019, September 29). Practice Makes Perseverance. Retrieved from Character Lab:www.characterlab.org.

Duckworth, A. L. (2013, April). Grit: The Power of Passion and Perseverance. Retrieved from Ted Talk: https://www.ted.com.

Duckworth, A. L., Kirby, T. A., Tsukayama, E., Berstein, H., \& Ericsson, K. A. (2011). Deliberate Practice Spells Success: Why Grittier Competitors Triumph at the National Spelling Bee. Social Psychological and Personality Science, 2(2), 174-181.

Duckworth, A. L., Quinn, P. D., Lynam, D. R., Loeber, R., \& Stouthamer-Loeber, M. (2011). Role of Test Motivation in Intelligence Testing. PNAS, (pp.7716-7720).

Dunn, K. M. (2018). Investigating Parenting Style and College Student Grit at a Private Mid-Sized New England University. Johnson \& Wales University.

Dweck, C. (2015, September 22). Carol Dweck Revisits the 'Growth Mindset'. Retrieved from Education Week: https://www.edweek.org/.

Dweck, C. S., Walton, G. M., \& Cohen, G. L. (2014). Academic Tenacity: Mindsets and Skills that Promote Long-Term Learning. Bill \& Melinda Gates Foundation. Retrieved from https://eric.ed.gov/?id=ED576649.

Evans, P., Martin, A. J., \& Ivcevic, Z. (2018). Personality, Coping, and School Well-Being: an Investigation of High School Students. Social Psychology of Education, 1061-1080.

Ford, D. Y. (2014). Segregation and the Underrepresentation of Blacks and Hispanics in Gifted Education: Social Inequality and Deficit Paradigms. Roeper Review, 36(3), 143-154.

Gravetter, F. J., \& Forzano, L. B. (2012). Research Methods for the Behavioral Sciences (4th ed.). Belmont, CA: Wadsworth.

Hair, J. F., Babin, B. J., Anderson, R. E., \& Black, W. C. (2018). Multivariate Data Analysis, 8th Edition.Cengage India. 
Hanford, E. (2012, October 2). How Important is Grit in Student Achievement. Retrieved from KQED: https://www.kqed.org/mindshift/24110/how-important-is-grit-in-studentachievement.

Harefa, A. (2010). Mindset Therapy: Mindset Therapy about the Meaning of Learn, Unlearn, and Relearn. Jakarta: Gramedia Pustaka Utama.

Havewala, M. C. (2012). The Effects of Perceived Parenting Styles on Psychopathology, Attachment, Self Esteem and Grit in American and Indian Students. American University. American University. Retrieved from American University Digital Research Archive: https://dra.american.edu.

Hochanadel, A., \& Finamore, D. (2015). Fixed and Growth Mindset in Education and How Grit Helps Students Persist in the Face of Adversity. Journal of International Education Research, 47-50. Hossaini, S. S., Boogar, I., \& Najafi, M. (2017). Predicting General Well-Being Based on Resiliency

Protective Factors and Demographics in Adolescents: The Mediating Role of Emotional Stability. International Journal of School Health, 4(2).

Jach, H. K., Sun, J., Loton, D., Chin, T.-C., \& Waters, L. E. (2017). Strengths and Subjective Wellbeing in Adolescence: Strength-Based Parenting and the Moderating Effect of Mindset. Journal of Happiness Studies, 567-586.

Jin, B., \& Kim, J. (2017). Grit, Basic Needs Satisfaction, and Subjective Well-Being. Journal of Individual Differences, 38(1), 29-35.

Jito, Subianto. 2013. The Role of Families, Schools and Society in Formation of Quality Character. Journal of Islamic Education Research Volume 8 No. 2, h. 337.

Kartikowati, E., \& Zubaedi. (2020, March 8). Learning Patterns of 9 Pillars of Character in Early Childhood and Its Dimensions. Jakarta: Prenadamedia Group. Retrieved from http://schoolcharacter.sch.id/.

King, R. B. (2017). A Fixed Mindset Leads to Negative Affect: the Relations Between Implicit Theories of Intelligence and Subjective Well-Being. Zeitschrift Für Psychologie, 225(2), 137-145.

Kristiyani, T. (2016). Self-Regulated Learning Concepts, Implications, and Challenges for Students in Indonesia. Yogyakarta: Sanata Dharma University Press.

Lampropoulou, A. (2018). Personality, School and Family: What is their Role in Adolescents' Subjective Well-Being. Journal of Adolescence, 67, 12-21.

Lester, L., \& Cross, D. (2015). The Relationship Between School Climate and Mental and Emotional Wellbeing Over the Transition from Primary to Secondary School. Psychology of Well-Being, 5(1).

Lickona, T. (2015). Educating for Character: Educating for Character Building. Jakarta: Earth Literacy. Madyawati, L. (2016). Language Development Strategies in Children. Jakarta: Prenadamedia Group.

McCain, B. (2017). Effects of Teacher Grit on Student Grit and Reading Achievement: a Mixed-Methods Study. Theses and Dissertations.

Megawangi, Ratna. (2010). Character Education is the Right Solution to build the Nation. Jakarta: IHF (Indonesian Heritage Foundation). 
Mujiburrahman, (2011), The Relationship Between Education, Motivation and Work Culture With Employee Performance (Study at the East Aceh District Inspectorate). Journal of Public Administration, 1 (2):160-169.

Nanda, A., \& Widodo, P. B. (2015). Self-Efficacy in terms of School Well-Being in Vocational High School Students in Semarang. Empathy Journal, 4, 6.

Paunesku, D., Walton, G. M., Romero, C., Smith, E. N., Yeager, D. S., \& Dweck, C. S. (2015). Mind-Set Interventions are a Scalable Treatment for Academic Underachievements. Psychological Science, 26(6), 784-793.

Polirstok, S. (2017). Strategies to Improve Academic Achievement in Secondary School Students: Perspectives on Grit and Mindset. SAGE Open, 7(4), 215824401774511.

Renaud-Dubé, A., Guay, F., Talbot, D., Taylor, G., \& Koestner, R. (2015). The Relations between Implicit Intelligence Beliefs, Autonomous Academic Motivation and School Persistence Intentions: A Mediation Model. Social Psychology of Education: An International Journal, 18(2), 255-272.

Ricci, M. C. (2013). Mindsets in the Classroom: Building a Growth Mindset Learning Community. Prufrock Press.

Ricci, M. C. (2015). Ready-to-Use Resources for Mindsets in the Classroom: Everything Educators Need for Building Growth Mindset Learning Communities. Prufrock Press.

Ricci, M. C. (2016). Mindsets for Parents: Strategies to Encourage Growth Mindsets in Kids. Prufrock Press.

Rosyadi, A. K., \& Laksmiwati, H. (2018). The Relationship between Grit and Subjective Well-Being in Psychology Students at the State University of Surabaya Class 2017. Journal of Psychology, 05, 6.

Sanguras, L. (2017). Grit in the Classroom: Building Perseverance for Excellence in Today's Students. Prufrock Press.

Santrock, J. W. (2011). Children 10th Edition. New York: McGraw-Hill Company.

Schunk, D. H. (2012). Learning Theories an Educational Perspective (6th ed). Boston: Pearson Education Inc.

Seligman, M. E. (2011). Flourish: A Visionary New Understanding of Happiness and Well-Being. New York, NY, US: Free Press.

Sembiring, T. (2017). Mindset Measurement Tool Construction. Journal of Psychology, 1(1).

Shaari, Z.H., Amar, A., Harun, A. B., \& Zainol, M.R. (2017). Exploring the Mindsets and WellBeing of Rural Secondary School Students in Perak, Malaysia. Global Business and Management Research: An International Journal, 9(1), 728-737

Siswina, T., Shahib, M. N., \& Rasyad, A. S. (2016). The Effect of Educational Stimulation on the

Intelligence Development of Children Aged 3-6 Years. Scientific Journal of Midwives, 1(2). Stoffel, J. M., \& Cain, J. (2018). Review of Grit and Resilience Literature Within Health Professions Education. American Journal of Pharmaceutical Education, 82(2).

Sturman, E. D., \& Zappala-Piemme, K. (2017). Development of the Grit Scale For Children and Adults and its Relation to Student Efficacy, Test Anxiety and Academic Performance. Learning and Individual Differences, 59, 1-10. 
Surya, Y. F. (2017). Application of Problem Based Learning Learning Model to Improve Mathematics Learning Outcomes for Fourth Grade Students at SDN 016 Langgini, Kampar Regency. Scholar's Journal: Journal of Mathematics Education, 1(1), 38-53.

Surya, Y. F. (2017). The Use of Learning Capital for 21st Century Character Education in Early Childhood. Journal of Early Childhood Education, 1(1), 52-61.

Teach, B. (2015). Growth Mindset and Grit Literature Review. Wellington Learning and Research Centre. Retrieved from https://www.wellingtoncollege.org.uk.

Tian, L., Liu, B., Huang, S., \& Huebner, E. S. (2012). Perceived Social Support and School Well-Being among Chinese Early and Middle Adolescents: The Meditational Role of Self-Esteem. Social Indicators Research, 113(3).

Tough, P. (2012). How Children Succeed: Grit, Curiosity and the Hidden Power of Character. Houghton Mifflin Harcourt.

Wahidah, F. R., Riyanto, \& Lucia, R. (2019). The Role of Persistence in the Relationship between Growth Mindset and School Well-Being Middle School Students. Talents, 4(2).

Waithaka, A. G., Furniss, T. M., \& Gitimu, P. N. (2017). College Student Mind-Set: Does Student- Parental Relatinshop Influence the Student's Mind-Set?

Waluyo, M. (2016). Easy Fast Precise Use of Amos Tools in Applications (SEM). UPN "Veteran" East Java.

Wijayanti, P. A. K., \& Sulistiobudi, R. A. (2018). Peer Relation as the Main Predictor of School Well- Being of Elementary School Students. Journal of Psychology, 17(1), 56.

Yeager, D. S., \& Dweck, C. S. (2012). Mindsets that Promote Resilience: When Students Believe that Personal Characteristics Can Be Developed. Educational Psychologist, 47(4), 302-314.

Zeng, G., Hou, H., \& Peng, K. (2016). Effect of Growth Mindset on School Engagement and Psychological Well-Being of Chinese Primary and Middle School Students: The Mediating Role of Resilience. Front Psychol, 29(7).

Zhao, Y., Niu, G., Hou, H., Zeng, G., Xu, L., Peng, K., \& Yu, F. (2018). From Growth Mindset to Grit in Chinese Schools: The Mediating Roles of Learning Motivations. Frontiers in Psychology, 9.

Zintz, S. (2018). Effectiveness of a Growth Mindset in Education. Northwestern College. 